\title{
Jak zmieniał się Wydział Matematyki, Informatyki i Mechaniki Uniwersytetu Warszawskiego w latach 1991-2016
}

STRESZCZENIE. W artykule przedstawiono ewolucyjne zmiany, które zachodziły na Wydziale Matematyki, Informatyki i Mechaniki Uniwersytetu Warszawskiego w latach 1991-2016. Wynikały one z uwarunkowań zewnętrznych (zmiany ustrojowe), rosnącego znaczenia informatyki, a także refleksji środowiska. Katalizatorem zmian stało się w 1991 r. przeniesienie Wydziału do innego budynku, wymagającego modernizacji na jego potrzeby. W nowej siedzibie podjęto program większego upodmiotowienia pracowników, integracji środowiska Wydziału oraz wykorzystania efektu synergii wynikającego z obecności matematyków i informatyków w ramach jednego Wydziału. WMIM starał się o utrzymanie spoistości Uniwersytetu m.in. poprzez zainicjowanie i przeprowadzanie wspólnej rekrutacji na studia, wprowadzenie Uniwersyteckiego Systemu Obsługi Studiów, a także zabieganie o zajęcia usługowe dla innych wydziałów. Ponadto przedstawiono wspólne przedsięwzięcia WMIM z innymi ośrodkami matematycznymi w kraju. WMIM na długo przed formalnym przyjęciem wymagań procesu bolońskiego wprowadził licencjat, a także uelastycznił program studiów, ułatwiając studentom wybór przedmiotów oraz zapewniając transparentność studiów. Wyzwoleniu inicjatywy młodych badaczy służyło spłaszczanie struktury organizacyjnej, prowadzenie transparentnej polityki kadrowej oraz funkcjonowanie systemu motywacyjnych dodatków do wynagrodzenia. Podkreślono, że globalny charakter nauk matematycznych i tradycja warszawskiej szkoły matematycznej stanowią zasadniczy czynnik kształtowania hierarchii wartości i ambicji środowiska.

SŁOWA KLUCZOWE: Wydział Matematyki, Informatyki i Mechaniki UW, zmiana, integracja, rekrutacja, zajęcia usługowe, system boloński, USOS, mobilność, chów wsobny, współdzielenie zasobów, indywidualizacja, podmiotowość, transparentność, standardy, wynagrodzenia

\section{Wstęp}

Uczelnie i ich wydziały są instytucjami długiego trwania, a Uniwersytet Warszawski szczyci się wybitnymi osiągnięciami warszawskiej szkoły matematycznej okre- 
su międzywojennego. W okresie powojennym matematyka, a potem i informatyka również cieszyły się renomą. Punktem wyjścia tego artykułu jest rok akademicki 1990/1991, bo był to rok wielkich zmian w Polsce, także w szkolnictwie wyższym. Ustawa z 12 września 1990 r. określiła na nowo ład akademicki i ustaliła początek kolejnej kadencji władz akademickich na 1 grudnia 1990 r. Do zewnętrznych uwarunkowań w przypadku Wydziału Matematyki, Informatyki i Mechaniki Uniwersytetu Warszawskiego (w skrócie Wydział lub WMIM) doszła nagła konieczność zmiany siedziby oraz postępująca od $1991 \mathrm{r}$. emancypacja wydziałów UW. Te okoliczności stanowiły impuls do przemyślenia od nowa wielu aspektów funkcjonowania społeczności Wydziału.

Bardzo ważnym motywem przemian WMIM była rosnąca rola informatyki we wszystkich dziedzinach życia oraz związane z tym zainteresowanie studiami informatycznymi. Rozwój Internetu i powstanie globalnej sieci WWW (1990) stanowiło wyzwanie nie tylko naukowe i dydaktyczne, ale także w sferze zastosowania go w codziennym funkcjonowaniu uczelni. Wprowadzenie licencjatu (1992), zapoczątkowanie procesu bolońskiego (1999) oraz nowe prawo o szkolnictwie wyższym (2005), ustawa o finansowaniu nauki i ich nowelizacje były kolejnymi ważnymi bodźcami.

Minione ćwierć wieku to okres bardzo pomyślny dla WMIM. Prace autorów z WMIM są stale obecne w czołowych czasopismach naukowych oraz na prestiżowych konferencjach międzynarodowych. Pracownicy Wydziału są laureatami wielu nagród i beneficjentami prestiżowych grantów krajowych i zagranicznych (ERC, NSF, NCN i in.). Podejmowane są nowe, aktualne tematy badawcze. Studenci osiągają znakomite wyniki w międzynarodowych konkursach. Prowadzonych jest wiele działań popularyzujących matematykę i informatykę. Na studia trafia co rok znacząca grupa olimpijczyków, a progi wyników maturalnych niezbędnych do immatrykulacji są wysokie. Absolwenci WMIM są poszukiwani na rynku pracy, znajdują zatrudnienie w uczelniach, znanych globalnych korporacjach, a także rozwijają własne firmy. Wydział zajmuje czołowe miejsca w krajowych rankingach i ewaluacji; zrealizował tez wiele krajowych i europejskich programów.

$\mathrm{W}$ artykule skoncentrowano się na rozwiązaniach systemowych i instytucjonalnych. $\mathrm{Z}$ żalem pominięto merytoryczne omówienie ewolucji tematyki badań naukowych oraz najważniejszych osiągnięć. Hierarchiczna struktura nauk matematycznych sprawia, że byłoby to niedostępne dla niespecjalistów. Trzeba jednak zaznaczyć, że globalny charakter nauk matematycznych i stosunkowo wysoka pozycja międzynarodowa polskich matematyków i informatyków stanowią zasadniczy czynnik kształtowania hierarchii wartości i ambicji środowiska.

W ewolucji WMIM można wyróżnić kilka wątków przewodnich. U progu omawianego okresu było to dążenie do zintegrowania środowiska Wydziału, przekonania się, że współpraca i współdzielenie zasobów lokalowych, finansowych, kadrowych jest korzystniejsze dla realizacji podstawowych celów niż mechaniczny 
podział zasobów między jednostki organizacyjne. To podejście pozwoliło na bezkonfliktową ewolucję relacji między, mówiąc ogólnie, matematyką a informatyką. Uwolnieniu inicjatyw młodych badaczy i ułatwieniu ewolucji tematyki badawczej służyło spłaszczenie struktury organizacyjnej przez ograniczenie roli lub likwidację zakładów. Duże znaczenie ma również transparentny system dodatków do wynagrodzeń dla pracowników wyróżniających się osiągnięciami.

Dbałość o integrację Wydziału szła w parze z działaniami na rzecz spoistości Uniwersytetu. Zmiany w systemie rekrutacji, służące na początku pozyskiwaniu przez WMIM jak najlepszych kandydatów na obu kierunkach, zostały stopniowo wprowadzone w całej uczelni.

Mając na względzie zmieniający się rynek pracy dla matematyków i informatyków, WMIM przeprowadził w kilku krokach głęboką reformę studiów - zarówno merytoryczną, jak i organizacyjną. Zamiast bojkotować bolońską organizację studiów, wprowadzono ją na długo, zanim stała się obligatoryjna. Indywidualizacji programów studiów oraz transparentności służy stworzony na Wydziale Uniwersytecki System Obsługi Studiów, który jest dziś zainstalowany w ponad 50 polskich uczelniach.

Artykuł nie jest relacją bezstronnego badacza, lecz uczestnika opisywanych procesów ${ }^{1}$. Trudno więc o obiektywizm, lecz w zamian postaram się przedstawić motywacje, które stały za rozmaitymi rozwiązaniami. Wśród wielu dokumentów ważną podstawą, która służyła odświeżeniu pamięci, były coroczne sprawozdania dziekana WMIM, a także deklaracje wyborcze w kolejnych dziekańskich wyborach. Wyłania się z nich obraz konsekwentnego kierunku działania przy wykorzystaniu pojawiających się nowych możliwości.

\section{Pamiętny rok 1990/1991}

W 1990 r., wobec drastycznego wzrostu czynszów w Pałacu Kultury i Nauki, WMIM został zmuszony do szybkiego opuszczenia pomieszczeń zajmowanych tam od dziesięcioleci. Przeprowadzka do zdewastowanego budynku po Wojskowej Akademii Politycznej, wymagającego dopiero dostosowania do potrzeb WMIM, okazała się szansą na wprowadzenie nowych rozwiązań w funkcjonowaniu Wydziału. Kandydując po raz pierwszy na dziekana WMIM jesienią 1990 r., autor tak przedstawiał zasadnicze wyzwanie:

Potrzebne jest głębsze związanie wszystkich pracowników z Uniwersytetem. W tym celu niezbędne jest podmiotowe, indywidualne traktowanie każdego członka naszej społeczności. Szczególnie wśród ludzi nauki i studentów indywidualność musi być ce-

${ }_{1}^{1}$ Autor był dziekanem WMIM w latach 1990-1996 i 1999-2005. 
niona wysoko, a zespoły tworzone w celu wspólnego rozwiązywania konkretnych problemów (Jackowski 1990).

Te ogólne słowa miały jednak praktyczne przełożenie. Stopniowo ugruntowała się zasada alokacji zasobów (nie tylko pomieszczeń) z myślą o poszczególnych członkach społeczności, a nie o jednostkach organizacyjnych. „Podział łupów” w nowej siedzibie między instytuty i zakłady był zresztą utrudniony przez sukcesywne prace modernizacyjne różnych fragmentów budynku, a zatem konieczności koncentrowania działalności w coraz to innej jego części. Wobec perspektywy przenosin deklaracja podkreślała, że:

Podmiotowe traktowanie pracowników przez uczelnię musi m.in. wyrażać się w zapewnieniu każdemu indywidualnego miejsca pracy, dostępu do urządzeń technicznych nieobwarowanego poniżającym wymaganiem uzyskiwania rozmaitych podpisów, swobodnego dostępu do księgozbioru naukowego czy choćby oficjalnym powierzeniem nam kluczy do pomieszczeń, które użytkujemy. Takim zaufaniem obdarzają nas uczelnie, w których przebywamy na krótkich wizytach; jest przykre, że w swojej rodzimej firmie traktowani jesteśmy odmiennie. Nie mogąc zapewnić konkurencyjnych wynagrodzeń, stwórzmy sprawne, dobrze funkcjonujące i przyjazne miejsce pracy (Jackowski 1990).

Przeprowadzając się do innego budynku, postanowiono zaadaptować go tak, aby przestrzeń zachęcała pracowników i studentów do spędzania czasu na Wydziale, nie tylko w trakcie zajęć dydaktycznych. Chodziło przede wszystkim o to, żeby użytkownicy czuli się komfortowo w swoim miejscu pracy czy studiów. Przyjęto zasadę, że prawo do miejsca pracy nie może zależeć od przynależności pracownika do jednostki organizacyjnej Wydziału. Według przyjętych norm każdy nauczyciel akademicki miał prawo do miejsca w pokoju co najwyżej dwuosobowym, przy czym dopuszczono łączenie się w pary użytkowników niekoniecznie według klucza przynależności do tego samego zakładu czy nawet instytutu. Wszyscy dostali klucze do swoich pokoi i prawo do korzystania z nich przez całą dobę, 7 dni w tygodniu. Studentom zapewniano położone centralnie pokoje dla samorządu i warunki w przestrzeniach ogólnych umożliwiające naukę i wypoczynek, a także otwarte przez cały dzień sale dydaktyczne. Obserwowaliśmy stopniową zmianę obyczajów - starsi profesorowie, którzy z przyzwyczajenia wyniesionego z PKiN deklarowali, że potrzebują tylko wieszaka do płaszcza, chętnie przyjmowali propozycję własnego pokoju. Z biegiem lat rosła liczba osób, które regularnie spędzają całe dnie, pracując lub ucząc się w budynku WMIM. Ten ważny element integracji środowiska podkreślał prof. Andrzej Tarlecki, kandydując na dziekana w 2012 r.:

Jednym z celów działania nas wszystkich powinno być stworzenie tu nie tylko formalnego miejsca pracy i działalności naukowej, ale miejsca, gdzie chce się przychodzić i pracować wspólnie z szerokim gronem dobrze znanych, cenionych i lubianych kolegów i studentów (Tarlecki 2012). 


\section{Integracja Wydziału Matematyki, Informatyki i Mechaniki}

U progu transformacji, tak jak i dziś, w skład WMIM wchodziły trzy instytuty: Matematyki (IM), Informatyki (II) oraz Matematyki Stosowanej i Mechaniki (IMSM), z historycznie uwarunkowaną dominującą rolą Instytutu Matematyki. Wobec rosnącej roli informatyki we wszystkich dziedzinach życia i związanego z tym wzrostem zainteresowania studiami informatycznymi w środowisku informatyków dojrzewały tendencje do wyodrębnienia informatyki jako osobnego wydziału. Także matematycy stosowani podejmowali nowe inicjatywy. Tendencje odśrodkowe wpisywały się w szerszy kontekst, o którym wspominano w cytowanej deklaracji wyborczej autora:

Innym, jeszcze bardziej niepokojącym zjawiskiem jest postępujące w ostatnich latach upodobnianie się uczelni do fraktala poprzez reprodukowanie modelu organizacyjnego całości na każdym piętrze jej struktury. Te procesy trzeba powstrzymać (Jackowski 1990).

Na WMIM przeważał pogląd, że utrzymanie jego jedności będzie z korzyścią dla wszystkich trzech środowisk, bo mają one komplementarne względem siebie atuty. Konieczne były więc działania integracyjne.

Zwiększenie liczby bardzo dobrych kandydatów na studia informatyczne odbywało się kosztem ich odpływu ze studiów matematycznych - nawet laureaci olimpiady matematycznej częściej wybierali studia informatyczne. Informatyka dojrzewała jako osobna dyscyplina, co powodowało ograniczanie puli zajęć stricte matematycznych w programie studiów informatycznych na rzecz przedmiotów informatycznych. Spotykało się to ze sprzeciwami matematyków. Aby nieco wyciszyć protesty i przekonać, że proponowane zmiany są zgodne z trendem rozwoju informatyki, dziekan (matematyk) zwrócił się do kilku polskich profesorów informatyki zatrudnionych na dobrych zagranicznych uczelniach o opinię na temat propozycji zmian w programie oraz przedstawił na tablicy ogłoszeń porównanie z programami $\mathrm{w}$ dobrych zagranicznych uczelniach.

Innym przejawem ruchów tektonicznych na styku matematyki i informatyki było przejście grona specjalistów w zakresie analizy numerycznej z Instytutu Informatyki do Instytutu Matematyki Stosowanej i Mechaniki. Naukowi liderzy tej grupy oczekiwali większego zainteresowania przedmiotem swoich badań wśród studentów i pracowników matematyków, co nie całkiem się sprawdziło. Ta migracja była jednym z pierwszych testów podmiotowego traktowania pracowników przez władze Wydziału. Dziekan nie zgodził się na przeniesienie Zakładu Analizy Numerycznej in corpore, a jedynie przejście zainteresowanych pracowników, co uczynili wszyscy (11) poza jedną osobą. Niektórzy później trochę żałowali tej decyzji, ale mieli świadomość, że podjęli ją suwerennie. W tym samym trybie trzech logików 
przeniosło się z Instytutu Matematyki do Instytutu Informatyki, niedawno kolejna osoba. Migracje były wstrząsem w ustabilizowanej strukturze, lecz dowodziły jednocześnie, że granice merytoryczne między instytutami są płynne, i wskazywały na sensowność zachowania jedności wydziału.

Migracje naruszyły też dotychczas sztywny podział puli wydziałowych etatów między instytuty otwierając drogę do uczynienia puli etatów zasobem wspólnym. Udało się to osiągnąć na gruncie wspólnych wartości środowiska, przekonanego, że powinniśmy zatrudniać najlepszych młodych ludzi, niezależnie od „braków kadrowych" w tej czy innej jednostce lub dyscyplinie. Dziekan zobowiązał się, że najlepsi kandydaci do pracy będą zatrudnieni niezależnie od dawnych limitów etatowych w poszczególnych instytutach. W kolejnych latach znacząco wzrastało zatrudnienie w Instytucie Informatyki (wykres 1), bo coraz więcej bardzo dobrych studentów wybierało ten kierunek (lub oba kierunki).

Wykres 1. Liczba nauczycieli akademickich w instytutach WMIM w latach 1994-2016

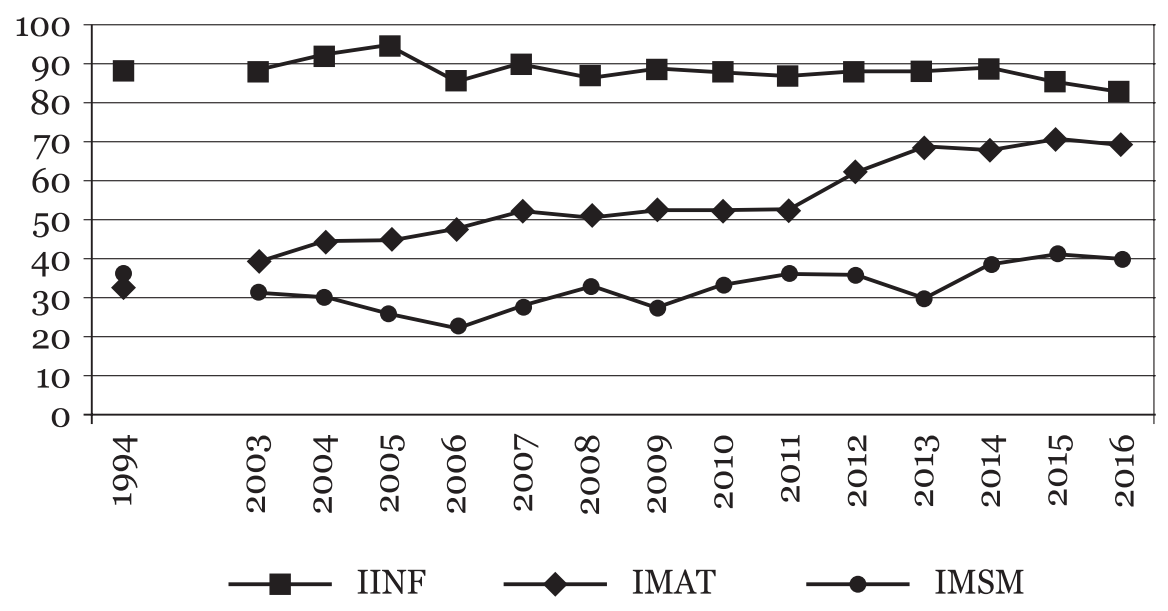

Źródło: opracowanie własne na podstawie sprawozdań dziekana WMIM.

Wzrost zatrudnienia informatyków pozwolił na zwiększenie rekrutacji na kieunek Informatyka (wykres 2). Na początku omawianego ćwierćwiecza proporcja liczby studentów matematyki do liczby studentów informatyki wynosiła 2:1, a obecnie studentów informatyki jest więcej niż matematyki (por. wykres 2).

Studia matematyczne stawały się studiami drugiego wyboru. Obowiązujące wówczas zasady rekrutacji zakładały, że kandydat ubiega się o przyjęcie na jeden kierunek studiów i w razie porażki, jedynie w miarę wolnych miejsc, w drugiej turze może ubiegać się o przyjęcie na inny kierunek. W efekcie dobrzy kandydaci na informatykę, którzy nie dostali się na te studia, ubiegali się o przyjęcie na pozostałe 
Wykres 2. Liczba studentów WMIM na kierunkach studiów w latach 1992-2016

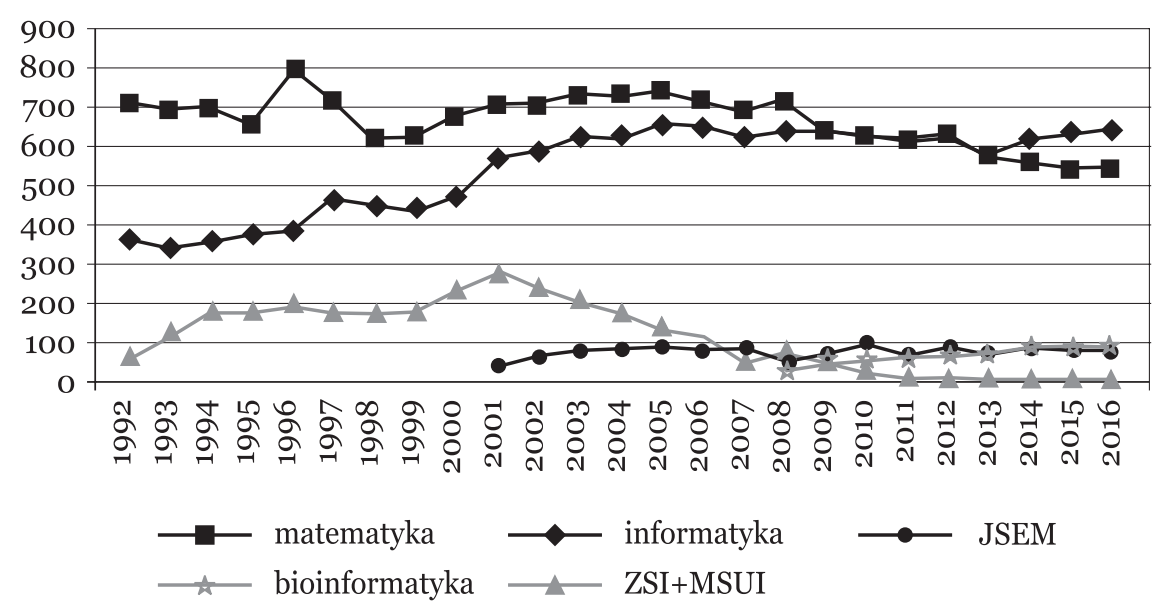

JSEM - Jednoczesne Studia Ekonomiczno-Matematyczne; ZSI+MSUI = wieczorowe (odpłatne) studia informatyczne, licencjackie (ZSI) i magisterskie (MSUI).

Źródło: opracowanie własne na podstawie sprawozdań dziekana WMIM.

wolne miejsca na matematyce, chociaż wyniki ich egzaminu wstępnego z matematyki były często znacznie lepsze od „ogona” rekrutacji na kierunek Matematyka. Żeby wyrównać szanse studiowania na WMIM została stworzona możliwość jednoczesnego ubiegania się o przyjęcie na oba kierunki. Kwalifikacja następowała według preferencji kandydata, aż do wyczerpania miejsc. Taka zasada działa do dziś, teraz w skali całej uczelni.

Druga, bardzo ważna innowacja polegała na zaproponowaniu kandydatom równoległego studiowania obu kierunków w ramach programu określanego jako Jednoczesne Studia Informatyczno-Matematyczne (w skrócie JSIM), prowadzącego do uzyskania dwóch dyplomów. Ku zaskoczeniu niektórych zainteresowanie tym programem było i jest bardzo duże, szczególnie w gronie olimpijczyków, a więc najlepszych kandydatów. Spośród około kilkudziesięciu olimpijczyków podejmujących corocznie studia na WMIM prawie połowa wybiera JSIM. Dziś wśród młodszych pracowników WMIM jest wielu absolwentów JSIM, co oczywiście dobrze służy wzajemnemu zrozumieniu matematyków i informatyków. Ma też bardzo pozytywny wpływ na badania, bowiem w XXI wieku nastąpił znaczący wzrost roli „czystej” matematyki w informatyce teoretycznej, a nawet jej praktycznych zastosowaniach.

Zwiększeniu atrakcyjności studiów matematycznych jako przygotowania do podjęcia pracy w biznesie służyło stworzenie (w 1999 r.), na podobieństwo JSIM, drugiego programu: Jednoczesnych Studiów Ekonomiczno-Matematycznych (JSEM, obecnie MSEM), co wymagało współpracy z Wydziałem Nauk Ekonomicz- 
nych ${ }^{2}$. Studia te stały się polem współpracy osób z obu instytutów matematycznych WMIM, zainteresowanych nowymi wówczas kierunkami zastosowań matematyki w finansach i ubezpieczeniach.

Integrujący charakter ma też makrokierunek Bioinformatyka i biologia systemów, bowiem zastosowania biologiczne matematyki i informatyki są silnie reprezentowane w II, jak też IMSM. Studia te prowadzone są we współpracy z wydziałami Biologii i Fizyki.

\section{Wydział Matematyki, Informatyki i Mechaniki na Uniwersytecie}

WMIM za ważną część swojej misji uznaje działania na rzecz Uniwersytetu jako całości, szczególnie utrzymywania jego spoistości. Od lat stara się przyjmować odpowiedzialność za jakość kształcenia w zakresie nauk matematycznych w całym UW. Należy życzyć dziekanowi Pawłowi Strzeleckiemu, aby udało mu się zrealizować zadanie przedstawione w deklaracji wyborczej:

Na nas [WMIM - S.J.] spoczywa odpowiedzialność za uczenie matematyki i informatyki licznych studentów wielu innych wydziałów, a także za wyznaczanie standardów tego nauczania, akceptowalnych dla naszych partnerów, ale i dla nas. Sprawa ma jeszcze jeden aspekt: to matematycy i informatycy powinni decydować, jakie warunki ma spełniać matematyk lub informatyk, zatrudniany na Uniwersytecie; ten pogląd zamierzam jasno reprezentować w kontaktach Wydziału z innymi jednostkami UW i z jego władzami (Strzelecki 2016).

WMIM jest największym w UW dostawcą tzw. zajęć usługowych - w tym roku akademickim przeznaczono na nie blisko 10 tys. godzin, a więc około 30-40 etatów nauczycieli akademickich. W ostatnim dziesięcioleciu liczba zajęć usługowych rosła (por. wykres 3), mimo że pewne wydziały zatrudniały „swoich” matematyków i rezygnowały z współpracy. Pojawiali się jednak nowi odbiorcy, także przedmiotów informatycznych.

Mając na uwadze upowszechnianie się narzędzi informatycznych we wszystkich dziedzinach badań, dydaktyki i życia codziennego, w 2005 r. WMIM wystąpił z projektem nazwanym w skrócie „П” (Przysposobienie Informatyczne), w ramach którego stworzono program szkoleń dla osób z różnych jednostek UW prowadzących zajęcia z technologii informatycznych.

WMIM jest także członkiem Kolegium Międzywydziałowych Indywidualnych Studiów Matematyczno-Przyrodniczych UW, w ramach którego działa także interdyscyplinarne studium doktoranckie - wielu studentów i doktorantów MISMaP korzysta z oferty WMIM.

${ }^{2}$ Wkrótce potem WNE wspólnie z Wydziałem Zarządzania stworzyły Międzykierunkowe Studia Ekonomiczno-Menedżerskie. 
Wykres 3. Liczba godzin zajęć usługowych w latach 2006-17

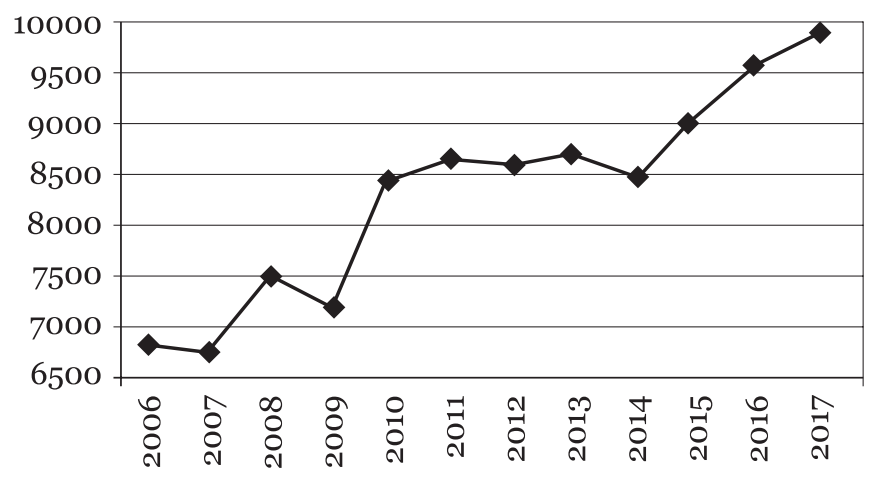

Źródło: opracowanie własne na podstawie sprawozdań Dziekana WMIM.

Zapewne najważniejszym wkładem WMIM w integrację UW było konsekwentne promowanie przeprowadzania wspólnej rekrutacji na studia (Jackowski, Mincer-Daszkiewicz 2004; 2005). Od 1995 r., w drodze poziomych porozumień wydziałów, stopniowo wprowadzano coraz więcej elementów współpracy przy przeprowadzaniu rekrutacji. Przeprowadzanie centralnych egzaminów z matematyki, języka polskiego oraz języków obcych stwarzało potrzebę wspólnej rejestracji kandydatów, która ułatwiała kandydatom jednoczesne ubieganie się o przyjęcie na kilka kierunków. WMIM zorganizował Centralną Rejestrację Kandydatów (CRK), do której wydziały przystępowały dobrowolnie. CRK była przeprowadzana przy pomocy skanowanych formularzy. Internet otworzył zupełnie nowe możliwości w 2002 r. po raz pierwszy odbyła się rejestracja mieszana, drogą tradycyjną lub internetową, a nowy system nazwano Internetową Rejestracją Kandydatów (IRK)3. Gdy wprowadzona została rekrutacja na studia na podstawie wyników matury, we współpracy z Centralną Komisją Egzaminacyjną powstał system KReM (Krajowy Rejestr Matur), z którego IRK pobiera wyniki matury i na podstawie algorytmu ustalanego przez jednostkę prowadzącą studia sporządza listę rankingową. Niedawno z inicjatywy WMIM wyniki matury z języka polskiego, matematyki i języka obcego zostały wprowadzone jako elementy kryteriów rekrutacyjnych na wszystkie kierunki prowadzone na UW. Po podjęciu decyzji o przyjęciu na studia kandydat zostaje „elektronicznie immatrykulowany”, a więc zarejestrowany w USOS (Uniwersytecki System Obsługi Studiów).

Papierowa dokumentacja przebiegu studiów, a nawet rozpowszechniające się pod koniec XX wieku oprogramowania instalowane w dziekanatach nie były odpo-

${ }^{3}$ Gazeta Wyborcza w warszawskim dodatku „Kujon polski” z dnia 25.03.2003 r. doniosła, że „UW to jedyna uczelnia, na którą można zarejestrować się całkowicie wirtualnie”. 
wiednimi narzędziami do kompleksowej obsługi elastycznej organizacji studiów. Uczelnia nie dysponowała pełnymi informacjami o studencie, jeśli pobierał naukę w wielu jednostkach. Studenci nie dysponowali narzędziem do kształtowania indywidualnych programów w skali uczelni. Nowoczesne bazy danych i Internet stwarzały zupełnie nowe możliwości - latem $1998 \mathrm{r}$. powstał pierwszy internetowy katalog przedmiotów wykładanych na UW4. Na marginesie warto dodać, że katalog ten był produktem ubocznym analizy potrzeb lokalowych na realizację zadań dydaktycznych ${ }^{5}$. Idea połączenia informatora z możliwością zapisywania się na zajęcia i rozliczania studentów wydawała się oczywista. Z inicjatywy WMIM powstało konsorcjum uniwersytetów, które otrzymało w ramach unijnego programu TEMPUS CM grant pn. NET na budowę nowego systemu informatycznego. System został nazwany Uniwersyteckim (a nie dziekanatowym czy wydziałowym) Systemem Obsługi Studiów, aby podkreślić, że ma służyć otwarciu oferty całego uniwersytetu dla wszystkich studentów. Podstawowe moduły USOS działały już w $2001 \mathrm{r}$. i były najpierw testowane u producenta, czyli WMIM, a także na Wydziale Matematyki i Informatyki Uniwersytetu Łódzkiego oraz w Instytucie Filozofii Uniwersytetu Kardynała Stefana Wyszyńskiego (Jackowski 2002). Do 2005 r. system był instalowany na innych wydziałach UW w drodze bezpośrednich porozumień WMIM z dziekanami. W 2005 r. Rektor UW wydał zarządzenie w sprawie prowadzenia dokumentacji studiów z wykorzystaniem systemu USOS. Bieżącą obsługą systemu zaczął zajmować się dział administracji centralnej UW.

Po zakończeniu projektu NET krajowi partnerzy stworzyli Międzyuniwersyteckie Centrum Informatyzacji (MUCI) z siedzibą na Uniwersytecie im. Adama Mickiewicza w Poznaniu, które stało się prawnym dysponentem USOS, a obecnie finansuje ze składek uczestników jego rozwój. Członkiem stowarzyszonym MUCI może zostać każda uczelnia zainteresowana wdrożeniem USOS i systemów pokrewnych. Wyłączną własnością UW są systemy KReM oraz IRK-MOST (służący do obsługi krajowej mobilności studentów), które są udostępniane pro publico bono wszystkim zainteresowanym uczelniom w kraju. Na WMIM pozostaje projektowanie nowych funkcjonalności wszystkich systemów i produkcja oprogramowania. USOS z wieloma towarzyszącymi aplikacjami jest standardowym systemem obsługi studiów: $49 \%$ studentów uczelni publicznych studiuje na uczelniach z systemem USOS, 33\% było rekrutowanych przez IRK, a 117 uczelni korzysta z systemu KReM.

Należy podkreślić, że tworzenie specyfikacji USOS i innych systemów wymagało zwerbalizowania transparentnej, logicznej struktury studiów, wprowadzenia podstawowych definicji oraz precyzyjnego opisania procesów składających się na przebieg studiów tak, żeby dały się zaimplementować w postaci programu kompu-

${ }^{4}$ Kopia zachowała się pod adresem https://www.mimuw.edu.pl/ sjack/katalog98/.

${ }^{5}$ Raport o zasobach przestrzennych w zgrupowaniu „Centrum” oraz o potrzebach przestrzennych na działalność naukową i dydaktyczną wybranych jednostek UW. http://www.mimuw.edu.pl/ sjack/ opera/rapzip15.pdf. 
terowego. Było to możliwe dzięki temu, że osoby zaangażowane w tworzenie USOS pełniły jednocześnie funkcje dziekańskie na Wydziale i miały możliwości wydawania zarządzeń dotyczących organizacji studiów na WMIM. Wiele wypracowanych wówczas rozwiązań zostało w następnych latach zapisanych w Regulaminie Studiów UW.

Upowszechnienie narzędzi internetowych wymagało opanowania ich przez nauczycieli akademickich (Jackowski 2004). Przy wsparciu Fundacji Stefana Batorego w latach 2000-2002 na WMIM został uruchomiony program pn. „Jakość przez jawność w dydaktyce uniwersyteckiej”. Przeprowadzono kursy korzystania z Internetu na różnych poziomach, w których wzięło udział ok. 200 uczestników z wielu jednostek UW (w tym ówczesny prorektor UW). W ramach programu zapewniano wsparcie merytoryczne i techniczne prowadzenia stron WWW zajęć dydaktycznych. Materiały były udostępniane na stronie $\mathrm{WWW}^{6}$.

\section{Partnerska współpraca}

Oprócz budowy silnych więzi wewnątrz UW WMIM dbał o podtrzymywanie partnerskich kontaktów z innymi ośrodkami matematyczno-informatycznymi, zarówno w ramach „poziomek” władz wydziałów i instytutów, jak też kontaktów bi- czy multilateralnych.

Od dziesięcioleci najbliższym partnerem WMIM jest Instytut Matematyczny PAN (IM PAN). W dawnych czasach wybitni profesorowie łączyli etatowe zatrudnienie w IM PAN i UW. Ta praktyka była stopniowo ograniczana.

Od $2001 \mathrm{r}$. istnieje porozumienie WMIM z IM PAN dotyczące współpracy w prowadzeniu studiów doktoranckich. Porozumienie obejmuje wspólną rekrutację na studia, przy zachowaniu przez kandydatów prawa wyboru instytucji, przy której będzie afiliowany, wyrównanie stypendiów oraz uzgodnienie organizacji studiów. Doktoranci IM PAN odbywają praktykę dydaktyczną na UW. Ponadto stworzono wspólne 7-letnie stanowiska dla młodych doktorów, polegające na przemiennej pracy rocznej pracy w IM PAN i w WMIM. Współpraca z IM PAN została pogłębiona poprzez stworzenie Warszawskiego Centrum Nauk Matematycznych (WCNM, finansowanego dotąd z funduszy KNOW), obejmującego matematykę i informatykę. Warto podkreślić, że ze środków KNOW było finansowanych wiele wspólnych przedsięwzięć z ośrodkami matematycznymi w całej Polsce.

Wychodząc naprzeciw potrzebom ośrodków mających mniejszy potencjał niż WMIM, szczególnie w zakresie informatyki stworzone zostały Środowiskowe Studia Doktoranckie (ŚSD), których partnerami były Uniwersytet Gdański, Uniwer-

\footnotetext{
${ }^{6}$ Archiwalne materiały programu „Jakość przez jawność” są zgromadzone pod adresem: https:// www.mimuw.edu.pl/ sjack/WMIM/batory/.
} 
sytet Mikołaja Kopernika oraz Uniwersytet Łódzki. ŚSD dawały szanse doktorantom z innych ośrodków korzystania z oferty WMIM oraz służyły wyrównywaniu standardów doktoratów w szybko zmieniającej się informatyce. Wspólnie z partnerskimi uczelniami został opracowany Regulamin ŚSD (który objął też Studium Doktoranckie UW) oraz szczegółowe plany studiów dla poszczególnych ośrodków. Doktoranci ŚSD otrzymali stypendia z macierzystych uczelni. Decyzje merytoryczne zostały zastrzeżone dla WMIM jako jednostki prowadzącej studia.

Ważną inicjatywą kształcenia doktorantów w skali kraju są prowadzone od 2006 r. wykłady „PhD Open”. Są to cykle zajęć z zagadnień współczesnej informatyki, skomasowane w dwu- lub trzydniowych sesjach, prowadzone przez czołowych specjalistów z kraju i zagranicy.

Dużą rolę w kształtowaniu modelu studiów doktoranckich odegrały Środowiskowe ogólnopolskie studia doktoranckie z nauk matematycznych, działające w latach 2009-2016, finansowane z programu UE Kapitał Ludzki. Powstały one z inicjatywy WMIM we współpracy z wydziałami matematyczno-informatycznymi uniwersytetów w Poznaniu, Toruniu, Lublinie, Krakowie, Wrocławiu, Katowicach oraz Instytutem Matematycznym PAN. Doktoranci pozostawali w macierzystych ośrodkach, jednak studia były prowadzone według wspólnych zasad (http://ssdnm.mimuw. edu.pl/plan), które zawierały m.in. wymagania mobilności doktorantów między ośrodkami. W okresie pobytu poza macierzystym ośrodkiem doktoranci otrzymywali specjalny dodatek do stypendium.

W tym roku powstał nowy program doktorancki w zakresie analizy i eksploracji danych (data science) prowadzony wspólnie przez WMIM oraz Wydział Matematyki i Nauk Informacyjnych Politechniki Warszawskiej.

\section{Mobilność i umiędzynarodowienie}

Globalny charakter nauk matematycznych i stosunkowo wysoka pozycja międzynarodowa polskich matematyków i informatyków stanowią zasadniczy czynnik kształtowania hierarchii wartości środowiska i punktów odniesienia. Nawet wśród starszych wiekiem pracowników WMIM istotną grupę stanowią osoby, które uzyskały doktorat za granicą, przeważnie w dobrych ośrodkach amerykańskich, a bodaj większość nauczycieli akademickich ma doświadczenie dłuższego pobytu w dobrym zagranicznym ośrodku. Powszechne jest uczestniczenie w międzynarodowych konferencjach, a wiele poważnych konferencji odbywa się w Polsce, co ułatwia nawiązywanie kontaktów naukowych. Systematycznie od wielu lat powstają wspólne publikacje z autorami zagranicznymi. W deklaracji wyborczej obecnego dziekana WMIM znalazły się następujące słowa: 
Konieczność utrzymania i wzmocnienia obecnej pozycji WMIM na mapie polskiej nauki jest czymś bezdyskusyjnym; utrata tej pozycji byłaby po prostu porażką. Punktów odniesienia powinniśmy szukać w skali międzynarodowej - to na niej warto przesuwać się w górę (Strzelecki 2016).

Poniżej omawiamy przejawy współpracy instytucjonalnej, choć bardzo wiele kontaktów ma charakter indywidualny. Ogromny wpływ na zwiększenie mobilności krajowej i kontaktów międzynarodowych miało uzyskanie statusu KNOW przez wspomniane konsorcjum WCNM. W jego ramach utworzono stanowiska podoktorskie, badawcze oraz prestiżowe profesury - we wszystkich przypadkach obsadzane w drodze postępowań konkursowych, do których zgłaszają się kandydaci z całego świata. Podwyższone stawki stypendiów i wynagrodzeń dla gości powodowały zwiększenie zainteresowania pracą w naszym kraju. Razem z innymi grantami realizowanymi na WMIM, w szczególności kilkoma grantami ERC, zaowocowało to widocznym zwiększeniem obecności obcokrajowców w życiu naukowym WMIM, także zatrudnionych na etatach naukowych i naukowo-dydaktycznych.

WMIM łączą umowy o wymianie studentów z kilkunastoma uczelniami europejskimi w ramach programu ERASMUS. Dwie z nich dotyczą wspólnych programów dyplomowych. Studenci korzystający z tych programów przygotowują prace magisterskie pod kierunkiem pary opiekunów z obu uczelni i spędzają ostatni rok studiów w uczelni partnerskiej.

WMIM stara się o to, aby naszymi partnerami były silne ośrodki (np. wspólny program magisterski łączy nas z École Polytechnique pod Paryżem). Wymaganie symetrii wymiany w programie Erasmus powoduje jednak, że mimo dobrych relacji naukowych uczelnie z wyższej półki odnoszą się z rezerwą do zawierania umów z UW.

W ramach multilateralnej współpracy z uniwersytetami w Pradze i Heidelbergu prowadzony był program studium doktoranckiego pn. „Metody matematyczne w badaniu procesów fizycznych”, sponsorowany przez Fundację na rzecz Nauki Polskiej. FNP wspierała także wiele innych przedsięwzięć WMIM.

WMIM nie prowadzi pełnych programów studiów w języku angielskim, bo nie ma takiego zapotrzebowania. Jednak dowolny przedmiot na studiach II stopnia jest prowadzony w języku angielskim, jeśli pojawi się uczestnik nieznający polskiego (np. student ERASMUS). Zakłada się, że każdy wykładowca posiada odpowiednie kwalifikacje (choćby wynikające z wygłaszania referatów na międzynarodowych konferencjach) i z tytułu prowadzenia zajęć po angielsku nie otrzymuje dodatkowych beneficjów. Język angielski nie stanowi też poważnej bariery dla polskich studentów; wielu włada nim bardzo dobrze.

Studenci WMIM biorą z powodzeniem udział w międzynarodowych zawodach. Najsłynniejsze to Akademickie Mistrzostwa Świata w Programowaniu Zespołowym (ang. ACM International Collegiate Programming Contest, ICPC). Drużyny z UW 
jako z jedynej uczelni na świecie awansowały do finałów 23 razy, a dwukrotnie zdobyły mistrzostwo świata (Madey 2010). Dziś wśród pracowników WMIM jest obecnie ponad 20 laureatów tych zawodów, należących do naukowej czołówki informatyki (niektórzy po habilitacji, a dwóch jest laureatami grantów ERC).

Także projekt USOS, zapoczątkowany w ramach programu UE, zachowuje międzynarodowy charakter. Zespół USOS uczestniczy w projektach informatycznych integrujących systemy do obsługi toku studiów w całej Europie (a także poza) m.in. w międzynarodowych projektach: Erasmus without Paper, projekcie e-QuATIC oraz EMREX. Twórcy USOS biorą udział w pracach organizacji European University Information Systems (EUNIS), a w 2007 r. MUCI, za stworzenie USOS otrzymało nagrodę EUNIS Elite Award. Obecnie zespół USOS bierze udział w pracach grupy Rome Student Systems and Standards Group ( $\left.\mathrm{RS}_{3} \mathrm{G}\right)$ i inicjatywy znanej pod nazwą Groningen Declaration.

\section{6. Łowienie talentów}

WMIM, a także indywidualnie wielu członków jego społeczności, przywiązuje wielką wagę do opieki nad zdolną młodzieżą. Jest to ogromnie ważne dla utrzymania wysokiego poziomu kadry naukowo-dydaktycznej, bo jej rekrutacja wciąż opiera się na „chowie wsobnym”. Wyszukiwanie młodzieży utalentowanej matematycznie rozpoczyna się poprzez Krajowy Fundusz na rzecz Dzieci (KFD). Ogromną rolę odgrywają w tym olimpiady matematyczna i informatyczna, a także specjalne licealne klasy matematyczne, prowadzone pod opieką WMIM. Rozwinięte są także działania popularyzatorskie (wykłady, warsztaty, konkursy), szczególnie skupione wokół wydawanego przez UW przy współpracy towarzystw naukowych legendarnego miesięcznika popularno-naukowego Delta, którego 500. numer niedawno był świętowany. Dziś wśród czołowych pracowników WMIM jest wiele osób, które podążały ścieżką: zawody szkolne lub olimpiady - KFD - JSIM - zawody programistyczne i matematyczne dla studentów. Ci pracownicy, angażując się w opiekę nad młodszymi koleżankami i kolegami podążającymi tą samą drogą, tworzą „,sztafetę pokoleń”.

Starania o najlepszych kandydatów na studia przynoszą efekty - co roku kilkudziesięciu finalistów i laureatów olimpiad podejmuje studia na WMIM. Stosunkowo wysoki jest próg punktowy przyjęć na studia licencjackie: w ub. roku wyniósł 85\% punktów na informatykę i 72\% punktów na matematykę (liczba punktów odzwierciedla przede wszystkim wyniki rozszerzonej matury z matematyki). Od wielu lat WMIM monitoruje wskaźnik atrakcyjności studiów, którym jest stosunek liczby podejmujących studia do liczby zakwalifikowanych (Offer Acceptance Rate). Wynosi on średnio w ciągu ostatnich 10 lat w przypadku Informatyki ok. 72\%, a Matematyki ok. 52\%. Na jego wysokość mają wpływ zmieniające się zasady rekrutacji, 
umożliwiające kandydatom jednoczesne ubieganie się o przyjęcie na wiele uczelni krajowych i zagranicznych. Jest to znacznie bardziej miarodajny wskaźnik preferencji niż tradycyjny stosunek liczby kandydatów do liczby miejsc. Interesujące byłoby dokonanie analizy porównawczej na różnych kierunkach i uczelniach oraz wyciągnięcie wniosków.

\section{Indywidualizacja programów studiów na Wydziale Matematyki, Informatyki i Mechaniki}

Postulat zmian w organizacji studiów znalazł się w deklaracji z 1990 r.

Nowa organizacja studiów powinna zmierzać do zapewnienia ich drożności, a także upowszechnienia indywidualnych programów kształcenia (Jackowski 1990).

Milowym krokiem w realizacji tego programu była reforma studiów na WMIM przeprowadzona w 1995 r. Tak opisywana była jej filozofia w Informatorze dla studentów:

Indywidualizacja programu studiów wymaga sprecyzowania reguł partnerstwa uczelni i każdego studenta. Dawniej student był przez długi okres studiów przypisany do jednej grupy i podążając za nią niejako automatycznie spełniał stawiane mu wymagania. Miał niewiele możliwości dokonywania własnego wyboru przedmiotów i wykładowców - także dziś studia na różnych kierunkach różnią się znacznie pod tym względem. Podążając ku upowszechnienia indywidualizacji programów studiów, zamiast sztywnej „siatki” zajęć przedstawiamy studentom ofertę wykładów i innych zajęć oraz reguły dokonywania wyboru z tej oferty na kolejnych latach i etapach studiów, zapewniające, że zajęcia, w których student będzie uczestniczyl, stworzą sensowną całość. Wybór przedmiotów dokonywany jest poprzez rejestracje na zajęcia; student zalicza rok/semestr jeśli zbiór zaliczonych zajęć spełnia odpowiednie dla danego fragmentu studiów, warunki określone przez Radę Wydziału MIM (Uniwersytet Warszawski, WMIM, Informator, rok 1995).

Indywidualizacja studiów miała dwa wymiary. Po pierwsze, skorzystano z możliwości wydawania dyplomu licencjata i zamiast bojkotować bolońską strukturę studiów, wprowadzono nową organizację studiów pięcioletnich, dzieląc je na dwa etapy: licencjacki (3 lata) i magisterski (2 lata). Chodziło o to, żeby studenci, którzy „zacięli” się na pierwszych latach studiów, mieli możliwość wyjścia z dyplomem po trzech latach. Warunkiem wstępu na etap magisterski (czyli IV rok) było spełnienie wymagań licencjatu (formalne uzyskanie stopnia nie było konieczne). To ograniczenie oznaczało praktycznie, że studenci studiów magisterskich nie mogli mieć „warunków” po III roku studiów.

Po drugie, zostały znacząco zwiększone możliwości wyboru przedmiotów, szczególnie na kierunku Matematyka. Ponieważ na studia matematyczne trafiają osoby 
o bardzo zróżnicowanych zdolnościach i zainteresowaniach (na Informatykę konkurencja jest silniejsza) przedmioty obowiązkowe na etapie licencjackim były i są prowadzone w dwóch wersjach: podstawowej i rozszerzonej (jako przedmioty „, gwiazdką"). Na III roku etapu licencjackiego wprowadzono szeroką pulę przedmiotów do wyboru, dających studentom odpowiednie przygotowanie zarówno w przypadku kontynuowania magisterskich studiów informatycznych lub matematycznych, jak też podjęcia pracy zawodowej z dyplomem licencjata lub innych studiów. Rozszerzenia możliwości wyboru zajęć przez studentów przy zachowaniu ograniczeń wynikających z hierarchicznej struktury nauk matematycznych dokonano poprzez wprowadzenie czterech pakietów przedmiotów (nieformalnych specjalizacji). W każdym pakiecie występowały zarówno przedmioty obowiązkowe, jak i fakultatywne. Warunkiem otrzymania dyplomu licencjata było początkowo jedynie zaliczenie przedmiotów z jednego pakietu (dopiero po formalnym podzieleniu studiów jednolitych wprowadzono pracę licencjacką i egzamin). Do zaliczenia roku studiów licencjackich wystarczało uzyskanie odpowiedniej liczby punktów zaliczeniowych (niekoniecznie z przedmiotów jednego pakietu).

W ramach reformy zrezygnowano z prowadzenia wyodrębnionej specjalizacji nauczycielskiej, gdyż była ona postrzegana jako boczny tor dla słabszych studentów. Umożliwiono za to wszystkim studentom zaliczanie pakietu zajęć pedagogicznych w ramach puli przedmiotów do wyboru spoza podstawowego kierunku studiów. Okazało się, że byli tym zainteresowani również dobrzy studenci, nawet pojedynczy studenci Informatyki.

Podobne pod względem organizacyjnym zmiany zostały przeprowadzone nieco później na studiach informatycznych, z tym że pula przedmiotów obowiązkowych jest znacznie większa, a do wyboru odpowiednio mniejsza. Programy przedmiotów informatycznych są konstruowane z myślą, aby absolwenci zdobyli kompetencje niezbędne do utrzymania się na rynku pracy informatycznej w dłuższej perspektywie. To zadanie niełatwe wobec dynamicznych zmian technik IT. Elementem wielu przedmiotów są zajęcia w laboratoriach komputerowych, a zaliczenie tych zajęć jest warunkiem koniecznym zaliczenia przedmiotu. Egzamin licencjacki na kierunku Informatyka odbywał się w formie pisemnego testu, obejmującego wszystkie przedmioty; obecnie jest to publiczna „obrona” pracy.

Ważną rolę w kształceniu umiejętności pracy w zespole odgrywa przedmiot pn. Zespołowy projekt programistyczny. Zadania programistyczne są stawiane we współpracy z zewnętrznymi podmiotami (firmami lub instytucjami); a studenckie rozwiązania czasami są przez nie wdrażane. Programy tworzone w ramach przedmiotu wraz z opisami stanowią prace licencjackie. Także prace przy systemie USOS mają bardzo pozytywny wpływ na proces dydaktyczny, głównie w zakresie inżynierii oprogramowania i baz danych, pozwalając studentom bezpośrednio uczestniczyć w dużym nowatorskim przedsięwzięciu programistycznym. Do dziś powstały setki prac licencjackich i magisterskich poświęconych rozmaitym fragmentom tego systemu. 
W organizacji etapu magisterskiego kluczową rolę odgrywają seminaria magisterskie. Prowadzący seminarium magisterskie zatwierdzają wybór przedmiotów dokonywany przez jego uczestników. Warunkiem zaliczenia seminarium na IV roku (pierwszym roku etapu magisterskiego) jest ustalenie tematu pracy magisterskiej, a zaliczenia V roku - złożenie pracy magisterskiej opiekunowi.

Organizacja studiów w formule, $5=3+2$ " uczyniła formalnością dostosowanie się do ustawowego wymagania wyodrębnienia studiów licencjackich i magisterskich. Największym problemem było znaczne zwiększenie liczby egzaminów dyplomowych. Internetowy system USOSweb znacznie uprościł obsługę indywidualnych programów studiów.

Szkoda, że stosunkowo mało kandydatów na studia II stopnia (i studia doktoranckie) pochodzi z innych uczelni, a ci, którzy podejmują naukę na WMIM, często nie mogą sprostać wymaganiom. Wynika to z dużej różnicy w poziomie studiów I stopnia. Doświadczenie WMIM potwierdza słuszność propozycji wprowadzenia „roku wyrównawczego” dla kandydatów zmieniających ośrodek lub kierunek studiów, zawartą w Strategii rozwoju szkolnictwa wyższego do roku 2020 (2010).

Mimo wieloletnich starań o uelastycznienie programu studiów pozostaje odczucie, że jest on zbyt sztywny, szczególnie na studiach licencjackich. Kandydując na dziekana w 2012 r., informatyk prof. Andrzej Tarlecki deklarował:

W moim odczuciu obecne studia licencjackie są zbyt sztywne, przeładowane i trudne, przy względnej latwości etapu magisterskiego. Uważam, że należy ograniczyć i uelastycznić wymagania twardego kanonu wiedzy matematycznej i informatycznej, wtłoczonego w pierwsze lata studiów. Zamiast tego potrzebne są elementy wyboru i alternatywne ścieżki studiowania, zarówno zorganizowane i oferowane stale, jak i zindywidualizowane dla potrzeb konkretnych studentów (Tarlecki 2012).

Niestety, niewiele udało się zmienić wobec dość sztywnego stanowiska obu środowisk - informatycznego i matematycznego, które nie są skłonne do zmniejszania wymiaru przedmiotów obowiązkowych. Powoduje to, że studia jednoczesne na obu kierunkach stają się bardzo wymagające. W okresie 2001-2017 dyplomy ukończenia obu kierunków, w ramach JSIM, MISMaP lub niezależnie, zdobyło 298 absolwentów. Tylko najwytrwalszych i najzdolniejszych stać na zdobycie dwóch dyplomów, a wielu studentów, którzy podejmują to wyzwanie, rezygnuje w trakcie.

\section{Transparentność i standardy}

Na WMIM dużą wagę przykłada się do dostępu do informacji, transparentności, standardów oraz procedur gwarantujących podejmowanie sprawiedliwych decyzji. W latach 1990-1992 ukazywał się co miesiąc biuletyn Wiadomości MIM, w 1995 r. wprowadzono zasadę rozsyłania informacji na konta mailowe pracowników. Po 
uruchomieniu portalu WWW tam przeniesiono ciężar przekazu informacji. W tej części bardziej szczegółowo zostaną omówione rozwiązania dotyczące organizacji studiów. Kluczową rolę odgrywa tu obecnie wspomniany USOSweb, zastępując wiele stosowanych wcześniej narzędzi. Dziś zarówno studenci, jak i nauczyciele mają w każdej chwili dostęp do informacji o programach, terminach, miejscu odbywania zajęć oraz ocenach.

Warunkiem koniecznym, aby student mógł podejmować decyzje o wyborze przedmiotów, jest posiadanie pełnej informacji merytorycznej i organizacyjnej. W celu ułatwienia układania indywidualnych planów studiów oraz mobilności wprowadzono zasadę, że wszystkie przedmioty odbywają się w cyklach semestralnych. Każdy przedmiot kończy się egzaminem lub finalnym zaliczeniem po semestrze, a nie jak dotąd czasami dopiero po roku. Stworzono system rejestracji na przedmioty i do grup ćwiczeniowych, najpierw za pomocą skanowanych formularzy, a następnie w Internecie, w ramach USOSweb. Szczegółowe informacje o przedmiotach kolejnego roku akademickiego są ogłaszane w maju poprzedniego roku. Zostały także wprowadzone ustalone (tzn. te same w każdym roku) terminy zajęć z obowiązkowych przedmiotów prowadzonych na WMIM.

WMIM zadbał o zapewnienie studentom równych szans sprawiedliwej oceny. Każdy przedmiot ma swojego koordynatora, zwykle wykładowcę, który jest zobowiązany dbać o wyrównany poziom zajęć i wymagań w grupach ćwiczeniowych. Do koordynatora należy ustalanie zadań na kolokwia i egzamin. Żeby uniezależnić los studenta od zróżnicowanych standardów zaliczeń ćwiczeń, do niedawna obowiązywała zasada, że do egzaminu w drugim terminie można przystępować niezależnie od uzyskania zaliczenia ćwiczeń rachunkowych (zasada nie dotyczyła zaliczenia laboratorium). Szkoda, że została zniesiona. W celu ułatwienia studentom przygotowania się do egzaminu, a wykładowcom ustalenia standardów wymagań w 2004 r. dziekan zarządził umieszczanie zadań z egzaminów w wydziałowym portalu. Niestety, wciąż napotyka to na opór ze strony pracowników i jest słabo egzekwowane.

Transparentności programów poszczególnych przedmiotów służą portale internetowe zawierające skrypty do obowiązkowych przedmiotów na Matematyce i Informatyce, będące także pomocą dla studentów i cieszące się zainteresowaniem użytkowników spoza UW. Wciąż w niewielkim stopniu wykorzystywana jest aplikacja do zdalnego nauczania Moodle, posiadająca wiele funkcjonalności pożytecznych także w klasycznej dydaktyce.

Studenci oceniają zajęcia, wypełniając ankietę w specjalnym module USOSweb. Wyniki ankiet są brane pod uwagę w okresowych ocenach pracowników i przy obsadzie zajęć. Nazwiska nauczycieli, którzy otrzymali najwyższe oceny studentów, są publikowane.

Ważnym elementem precyzowania zasad studiów magisterskich było określenie scenariuszy egzaminów dyplomowych oraz trybu składania i oceniania prac dyplomowych. Prace są składane do internetowego Archiwum Prac Dyplomowych (APD); 
przy czym student może złożyć pracę dopiero po przygotowaniu opinii o niej przez opiekuna. Egzamin nie sprowadza się wyłącznie do „obrony” pracy dyplomowej, bo zawiera pytania z programu studiów. Powołane zostało kolegium przewodniczących komisji egzaminów dyplomowych, co miało sprzyjać utrwalaniu standardu merytorycznego i organizacyjnego egzaminów. Po wprowadzeniu prac i egzaminów licencjackich w odniesieniu do nich zostały wprowadzone analogiczne zasady.

\section{Ewolucja struktury organizacyjnej}

W 1991 r. WMIM miał tradycyjną strukturę organizacyjną. Trzy instytuty były podzielone na zakłady, a w ramach Instytutu Informatyki działał Ośrodek Obliczeniowy. Dyrektor administracyjny wydziału szefował całej administracji. Dziekanat obejmował obsługę sekretarską dziekana, prodziekanów i Rady Wydziału, a także sprawy studenckie. Istniała odrębna sekcja finansowa, kierowana przez pełnomocnika kwestora. Każdy instytut miał odrębny sekretariat. Funkcjonowała biblioteka.

W celu lepszego powiązania administracji akademickiej (dziekana, prodziekanów i dyrektorów instytutów) z administracją zawodową w 1992 r. zrezygnowano z funkcji dyrektora administracyjnego. Wprowadzono sekcje i sekretariaty podlegające bezpośrednio odpowiednim osobom pełniącym funkcje w administracji akademickiej. Zwiększeniu efektywności i usprawnieniu obsługi nauczycieli akademickich służyła dokonana w 2005 r. integracja sekretariatów trzech instytutów we wspólnej przestrzeni przylegającej do gabinetów dyrektorów. W związku ze znaczącym przyrostem finansowania z grantów 2006 r. utworzono też wydziałową sekcję obsługi badań.

Miniaturyzacja komputerów oraz rosnące zapotrzebowanie na laboratoria dydaktyczne spowodowały utworzenie w miejsce Ośrodka Obliczeniowego, wydziałowego Laboratorium Komputerowego. Jest ono odpowiedzialne za utrzymanie infrastruktury informatycznej (w tym serwerów i sieci) oraz organizację zajęć laboratoryjnych dla studentów. W 1991 r. na WMIM powstało Interdyscyplinarne Centrum Modelowania Matematycznego i Komputerowego (znane później jako ICM), które w 1993 r. zostało przekształcone w jednostkę podstawową UW i otrzymało inną siedzibę.

Istotne zmiany zachodziły w strukturze wewnętrznej instytutów. Polegały one na ograniczeniu zadań lub likwidacji zakładów, czyli spłaszczeniu hierarchicznej struktury. Dotychczas pracownicy przez większość czasu swojej pracy zawodowej pozostawali w zakładzie kierowanym przez osobę, u której robili magisterium. Odejście od struktury zakładowej było więc formą redukowania negatywnych efektów „wsobnego chowu” oraz zachętą do aktualizacji zainteresowań naukowych. W 1992 r. w Instytucie Matematyki po długiej i emocjonalnej dyskusji rozwiązano dwa zakłady (a w następnych latach kolejne) i stworzono możliwość pozostawania 
poza zakładem przez pracowników ze stopniem co najmniej doktora. Miał to być jasny sygnał dla młodych pracowników, że wraz z doktoratem nadszedł czas ich naukowej samodzielności ${ }^{7}$. Asystenci bez doktoratu musieli mieć opiekuna naukowego, a praca naukowa miała koncentrować się wokół seminariów badawczych. Dziś 47 spośród 84 pracowników Instytutu Matematyki pozostaje w pięciu zakładach; pozostałych 37 jest poza zakładami, a ich bezpośrednim przełożonym jest dyrektor instytutu. Nazwy zakładów są podyktowane tradycją i pozostają czasem w luźnym związku z profilem naukowym ich członków. Ze względu na większą dynamikę zmian w informatyce struktura zakładowa w tym instytucie okazała się jeszcze bardziej archaiczna i w 2007 r. zdecydowano o rozwiązaniu wszystkich zakładów. Pracownicy tworzą nieformalne grupy badawcze, często skupione wokół grantów. Tylko trzeci instytut (IMSM), podzielony na cztery zakłady, zachował tradycyjną strukturę. W związku z rozwojem ekonomicznych zastosowań matematyki został utworzony międzyinstytutowy Zakład Matematyki Finansowej i Ubezpieczeniowej, pełniący głównie funkcję dydaktyczną. Osoby do niego przypisane zachowały afiliację w macierzystych instytutach.

\section{Polityka kadrowa i wynagrodzenia}

Ważnym elementem polityki kadrowej są standardy stosowane przy nadawaniu stopni i występowaniu o tytuł naukowy w zakresie nauk matematycznych. Uznano, że WMIM powinien stosować kryteria nieco wyższe od przeciętnych w kraju. W celu wykształcenia wydziałowych standardów doktoratów ustabilizowane zostały składy trzonów komisji doktorskich Rady Wydziału. Powstały komisje z grubsza odpowiadające profilom instytutów, z tym że w każdej z nich zasiadają przedstawiciele wszystkich instytutów. Wprowadzono zasadę prezentowania Radzie Wydziału profilu naukowego i dorobku kandydatów na recenzentów zewnętrznych. Gdy tylko prawo na to pozwala, powoływani są eksperci zagraniczni.

W 2000 r. zostały explicite sformułowane wydziałowe zasady polityki kadrowej WMIM, szczególnie awansów. Zasady te, z pewnymi modyfikacjami wynikającymi ze zmian przepisów, obowiązują do dziś. Są nieco ostrzejsze niż ogólne zasady stosowane na UW. Zgodzono się, że przy awansach na kolejne stanowiska wymagania nie powinny się ograniczać do zdobycia odpowiedniego stopnia czy tytułu naukowego. W szczególności uzyskanie tytułu naukowego nie daje automatycznego awansu na stanowisku profesora zwyczajnego. Postanowiono, że stanowisko profesora zwyczajnego powinno być zarezerwowane dla osób legitymujących się dorobkiem naukowym uznanym w świecie i wybitnymi osiągnięciami w pracy akademickiej. Sprecyzowano, że przy ocenie kandydatów na stanowisko profesora zwyczajnego bierze się pod uwagę, czy kandydat ma znaczny dorobek naukowy (uznanie w świe-

\footnotetext{
7 Przypomnijmy, że medal Fieldsa przyznawany jest matematykom, którzy nie ukończyli 40 lat.
} 
cie), czy wywarł istotny wpływ na rozwój danej dziedziny, czy jest uznanym specjalistą w uprawianej dziedzinie, liderem grupy badawczej, liderem dyscypliny w skali kraju. Brane są pod uwagę osiągnięcia dydaktyczne, wkład w kształcenie młodej kadry oraz aktywność organizacyjna na rzecz Wydziału lub Uniwersytetu.

Na koniec 2016 r. spośród 46 pracowników z tytułem naukowym 31 było zatrudnionych na stanowisku profesora zwyczajnego. Podobnie awanse osób habilitowanych na stanowisko profesora nadzwyczajnego nie są automatyczne. Już od kandydatów na stanowisko adiunkta wymaga się posiadania publikacji o zasięgu międzynarodowym oraz preferuje się kandydatów, którzy odbyli dłuższy staż w dobrym zagranicznym ośrodku.

Kierując się zasadą, że zależy nam przede wszystkim na najzdolniejszych kandydatach na nauczycieli akademickich, konkursy są ogłaszane do poszczególnych instytutów, ale z reguły bez precyzowania specjalności naukowej kandydata w warunkach konkursu.

Wydziałowa komisja konkursowa ma stabilny skład, pokrywający się ze składem komisji przeprowadzającej okresowe oceny nauczycieli akademickich. Tworzą ją przedstawiciele wszystkich trzech instytutów, co pozwala na spójną, obiektywną ocenę kandydatów ze względu na wspólne kryteria. Przeprowadzanie okresowych ocen ułatwia system internetowy EVA (-luation), będący modułem USOSweb. Pracownicy mają obowiązek wprowadzania publikacji do bazy PBN skąd są importowane do EVA. Warto podkreślić, że ocena dorobku ma charakter merytoryczny, a popularne wskaźniki bibliometryczne odgrywają jedynie pomocniczą rolę w ocenie dorobku, bowiem z różnych powodów nie oddają wagi osiągnięć ani w matematyce, ani w informatyce.

WMIM prowadzi restrykcyjną politykę zatrudniania etatowego osób emerytowanych, pozostawiając im oczywiście możliwości pracy badawczej oraz w razie potrzeby zatrudnienia na podstawie umowy o dzieło. Bardzo wyraźnie sformułował to obecny dziekan we wspomnianej już deklaracji:

Uważam, że regularne zatrudnianie młodych osób (przy zachowaniu wysokich standardów polityki kadrowej, kładących nacisk na regularny, stały rozwój naukowy pracowników) jest ważniejsze dla stabilności i przyszłości Wydziału, niż oferowanie dalszego etatowego zatrudnienia uczonym, którzy osiągnęli wiek emerytalny (Strzelecki 2016).

Wprowadzono w życie zasady konkursowego zatrudniania pracowników administracji. Wymagano, aby kandydaci do pracy posiadali wyższe wykształcenie uzyskane w publicznej uczelni. Postępowanie konkursowe obejmuje test sprawności posługiwania się narzędziami informatycznymi, w tym edytorem (redakcja prostego listu, czasem także po angielsku), prostym arkuszem kalkulacyjnym oraz Internetem (wyszukiwarka). Większość aktualnych pracowników administracji została zatrudniona w drodze takiego konkursu. 
Nieznaczne ograniczanie liczby pracowników administracji pozwalało na nieco lepsze wynagradzanie pozostałych, szczególnie wyróżniających się zaangażowaniem i kwalifikacjami. Wprowadzono zasadę, że wszelkie dodatkowe dochody pracowników administracji pochodzące ze źródeł pozostających w dyspozycji uczelni (premie i prace zlecone, np. na rzecz grantów) pozostają w gestii ich przełożonych akademickich, a władze dziekańskie starają się dbać o zachowanie właściwych proporcji. W ostatnich latach liczba pracowników administracji nieco wzrosła (do 36) w związku ze znacznym zwiększeniem zadań wynikających przede wszystkim z obsługi grantów badawczych i innych projektów odrębnie finansowanych.

Pewna swoboda pozostawiona przez Senat i rektora wydziałom UW w ustalaniu wysokości wynagrodzeń nauczycieli akademickich była wykorzystywana do ich podnoszenia ponad przeciętną uczelnianą. Szczególnie w latach znaczących podwyżek „inflacyjnych” było to możliwe dzięki zdyscyplinowanej polityce zatrudniania oraz dobrym wynikom wydziału w wewnętrznym podziale tzw. dotacji dydaktycznej.

Wynagrodzenia zasadnicze są ustalone odpowiednio dla każdego stanowiska nauczycieli akademickich. Nowością w stosunku do tradycji było podwyższenie wynagrodzeń starszych wykładowców nieco ponad wynagrodzenie adiunkta, co jest uzasadnione wyższym pensum dydaktycznym, a wynagrodzenia są wypłacane z dotacji dydaktycznej. Ukazywało to jednocześnie ważną rolę, jaką ta grupa pracowników odgrywa w działalności dydaktycznej WMIM, m.in. umożliwiając innym pracownikom większe skupienie się na badaniach.

Zróżnicowanie wynagrodzeń nauczycieli akademickich w zależności od ocen przełożonych jest realizowane $\mathrm{w}$ postaci dodatków specjalnych wypłacanych ze środków pozabudżetowych oraz DST i BW, według zasad zwanych „mechaniką kwantową". Przychylając się do opinii WMIM Senat UW w grudniu 1993 r. przyjął uchwałę pozwalającą na wypłacanie ze środków pozabudżetowych dodatków specjalnych do wynagrodzeń. Praktykowane od lat wypłacanie dodatków do wynagrodzeń z dotacji statutowej zostało zaakceptowane przez audytora w $2015 \mathrm{r}$.

Dodatki specjalne do pensji są przyznawane za osiągnięcia w pracy na WMIM na okres jednego roku przez dziekana na wniosek dyrektora instytutu. Wymiar dodatku jest określany w jednostkach podstawowych (kwantach). Wartość kwantu może zależeć od źródła finansowania i rodzaju kwantu - do systemu zostały włączone stypendia fundowane przez rektora, a w ostatnich latach z środków KNOW. Wysokość kwot przeznaczonych na dodatki, rodzaje kwantów, wartość kwantu każdego rodzaju, sposób kwantowania stypendium rektora i maksymalną liczbę kwantów (dodatku stałego oraz stypendium rektora), jakie może otrzymać jedna osoba, ustala dziekan w porozumieniu z dyrekcjami instytutów. Dziekan przyznaje każdemu z instytutów pulę kwantów na dodatki. Co kilka lat osobom, którym w mijającym okresie przyznawano najwyższe dodatki uznaniowe, część kwantów dziekan przenosi (na stałe) do wynagrodzenia zasadniczego. Posiadanie kwantów dodatku 
w wynagrodzeniu zasadniczym jest brane pod uwagę przy przyznawaniu dodatków na kolejne okresy i powoduje odpowiednie zmniejszenie maksymalnej wysokości dodatku uznaniowego dla osoby mającej zwiększone uposażenie. W 2016 r. wartość kwantu z funduszy wydziału wynosiła 250 zł (wysokość kwantu z innych źródeł, np. KNOW lub rektora UW, była wyższa), a maksymalny dodatek mógł wynosić 12 kwantów. Dziekan co roku przedstawia Radzie Wydziału sprawozdanie z działania mechaniki kwantów.

Osoby sprawujące funkcje zostały wyłączone z ogólnego systemu dodatków uznaniowych; dodatki dla nich wynikały z ogólnych zasad dodatków funkcyjnych w UW, a dodatki uznaniowe wypłacano na podstawie wniosków komisji złożonej z trzech „senioralnych” profesorów, niesprawujących żadnych funkcji na Wydziale. Zasady ustalone przez tę komisję na przełomie wieków obowiązują nadal.

\section{Podziękowania}

Korzystam z okazji, aby serdecznie podziękować moim koleżankom i kolegom, z którymi współpracowałem w latach sprawowania funkcji dziekana, a którzy w ogromnym stopniu przyczynili się do sukcesów WMIM: prodziekanom Stanisławowi Betleyowi (dziekanowi w latach 2005-2012), Józefowi Chaberowi, Janinie Jankowskiej, Markowi Kowalskiemu, Janowi Madeyowi, Janinie Mincer-Daszkiewicz oraz Krzysztofowi Moszyńskiemu. Do tego grona dołączam Andrzeja Tarleckiego (dziekana w latach 2012-2016) oraz Pawła Strzeleckiego (dziekana od 2016 r.), którzy wówczas sprawowali funkcje w instytutach. Dziękuję im za współpracę w latach przemian WMIM, a także za liczne uwagi do tego tekstu. Za uwagi dziękuję także mojej żonie Agnieszce Bojanowskiej, a ponadto Krzysztofowi Diksowi, Marcinowi Engelowi, Annie Gambin, Ninie Kancewicz-Hoffman, Tadeuszowi Krauze, Mirosławowi Lachowiczowi, Leszkowi Plaskocie, Janowi Oknińskiemu oraz redaktorowi tomu Markowi Kwiekowi. Pragnę tu życzliwie wspomnieć także zmarłego Władysława M. Turskiego, dziekana WMIM w latach 1996-1999.

\section{Literatura}

Jackowski, S. (1990). Wystapienie na zebraniu elektorów Wydziału Matematyki, Informatyki i Mechaniki Uniwersytetu Warszawskiego w dniu 21 XI 1990. https://www. mimuw.edu.pl/ sjack/WMIM/1990_deklarcja_SJ.pdf.

Jackowski, S. (2002). Uniwersytecki System Obsługi Studiów. Uniwersytet Warszawski: Pismo Uczelni, 1(7): 25-26.

Jackowski, S. (2004). Co Internet zmienia w tradycyjnej dydaktyce akademickiej? Nauka i Szkolnictwo Wyższe. 2(24): 135-140.

Jackowski, S., Mincer-Daszkiewicz, J. (2004). Elektroniczna immatrykulacja. Uniwersytet Warszawski: Pismo uczelni. 3(19): 20-22.

Jackowski, S., Mincer-Daszkiewicz, J. (2005). Przez Internet na studia. Forum Akademickie. 3: 41-43.

Katalog przedmiotów. https://www.mimuw.edu.pl/ sjack/katalog98/. 
Madey J. (2010). Kształcenie zindywidualizowane na Wydziale Matematyki, Informatyki i Mechaniki Uniwersytetu Warszawskiego, czyli „szlifowanie diamentów”. W: T. Borecki (red.), Wspótpraca szkót średnich i wyższych (t. XLVIII, rozdz. 3, ss. 13-22). Warszawa: Instytut Problemów Współczesnej Cywilizacji im. Marka Dietricha.

Program „Jakość przez jawność”. https://www.mimuw.edu.pl/ sjack/WMIM/batory/.

Raport o zasobach przestrzennych w zgrupowaniu „Centrum” oraz o potrzebach przestrzennych na działalność naukową i dydaktyczną wybranych jednostek UW. http://www.mimuw.edu.pl/ sjack/opera/rapzip15.pdf.

Strategia rozwoju szkolnictwa wyższego w Polsce do 2020 roku - drugi wariant (2010). Raport cząstkowy przygotowany przez konsorcjum Ernst \& Young Business Advisory oraz Instytut Badań nad Gospodarką Rynkową.

Strzelecki, P. (2016). Wydziat Matematyki, Informatyki i Mechaniki UW: moja perspektywa. 5.03.2016. https://www.mimuw.edu.pl/ pawelst/wybory_2016/WMIM_w_moich_oczach.pdf.

Tarlecki, A. (2012) List do spoleczności WMIM. 30.04.2012. https://www.mimuw.edu. pl/ sjack/WMIM/2012_deklaracja_AT.pdf.

Uniwersytet Warszawski, WMIM. Informator dla studentów I roku kierunku informatyka, I i II roku kierunku matematyka dziennych studiów magisterskich w roku akademickim 1995/96.

\section{How the Faculty of Mathematics, Informatics and Mechanics of the University of Warsaw has been changing during the years 1991-2016}

ABSTRACT. We describe how the Faculty of Mathematics, Informatics and Mechanics of the University of Warsaw (Faculty MIM for short) has been changing during the years 1991-2016. These changes were motivated by a change of the political system in Poland, affecting academic life, as well as the growing import_ance of Computer Science (Informatics). Moving MIM's faculty to another building was a catalyst for change, giving the community a chance to reevaluate various aspects of academic life. In the new environment faculty members were treated more as individual researchers rather than employees of various organizational units. Improved working conditions helped to create a sense of community. An import_ant goal was to achieve a synergy effect resulting from the close collaboration of mathematicians and computer scientists. The faculty of MIM acted against the fragmentation of the university, which was typical of Poland during the last decade of the 2oth century. It initiated a university-wide recruitment system for students, produced and introduced innovative software (University Study-Oriented System (USOS)) and paid special attention to service courses in mathematics and computer science. Long before the introduction of the Bologna system, the five-year curriculum at MIM was divided into bachelor and master programs that contained an extended range of elective courses. To meet the requirements of the quickly changing disciplines and to motivate young researchers, a flat organization structure of the Faculty was introduced. An import_ant element of a transparent Human Resources policy is a system of financial bonuses for the most active researchers and teachers. We emphasize that the global character of mathematical sciences, and the tradition of the Warsaw mathematical school, are key factors forming standards and values of the community. 
KEYWORDS: Faculty of Mathematics, Informatics and Mechanics University of Warsaw, change, University Study-Oriented System (USOS), recruitment of students, Bologna system, service courses, inbred of faculty, sharing resources, transparency, standards, financial bonuses

CYTOWANIE: Jackowski, S. (2017). Jak zmieniał się Wydział Matematyki, Informatyki i Mechaniki Uniwersytetu Warszawskiego w latach 1991-2016. Nauka i Szkolnictwo Wyższe. 2(50): 223-247. DOI: 10.14746/nisw.2017.2.11.

STEFAN JACKOWSKI - profesor nauk matematycznych, specjalista w zakresie topologii algebraicznej, współautor prac w czołowych globalnych pismach matematycznych m.in. Annals of Mathematics i Acta Mathematica, a także wielu publikacji w kraju dotyczących problemów szkolnictwa wyższego. Pełnił rolę koordynatora merytorycznego zespołu autorów „Strategii rozwoju szkolnictwa wyższego w Polsce do 2020 roku" przygotowanego przez konsorcjum Ernst \& Young Business Advisory oraz Instytut Badań nad Gospodarką Rynkową (2009/2010). Od 2012 r. jest członkiem Komitetu Ewaluacji Jednostek Naukowych. W latach 2005-2013 był prezesem Polskiego Towarzystwa Matematycznego, a od 2017 r. jest członkiem zarządu Europejskiego Towarzystwa Matematycznego. W różnym charakterze zasiadał przez 20 lat w Senacie Uniwersytetu Warszawskiego; w latach 19901996 i 1999-2005 był dziekanem WMIM, kilkukrotnie był wysuwany przez Kolegium Elektorów UW jako kandydat na rektora. E-mail: stefan.jackowski@uw.edu.pl. 